\title{
Cell-Free Hemoglobin and Its Scavenger Proteins: New Disease Models Leading the Way to Targeted Therapies
}

\author{
Dominik J. Schaer ${ }^{1,2,3}$ and Paul W. Buehler ${ }^{4}$ \\ ${ }^{1}$ Division of Internal Medicine, University Hospital, Zurich CH-8091, Switzerland \\ ${ }^{2}$ Center of Integrative Human Physiology University of Zurich, Zurich CH-8057, Switzerland \\ ${ }^{3}$ Center of Evolutionary Medicine, University of Zurich, Zurich $\mathrm{CH}-8057$, Switzerland \\ ${ }^{4}$ Laboratory of Biochemistry and Vascular Biology, Division of Hematology, Center for Biologics \\ Evaluation and Research, Food and Drug Administration, Bethesda, Maryland 20892 \\ Correspondence: dominik.schaer@usz.ch; paul.buehler@fda.hhs.gov
}

\begin{abstract}
Hemoglobin $(\mathrm{Hb})$ has multiple pathophysiologic effects when released into the intravascular space during hemolysis. The extracellular effects of $\mathrm{Hb}$ have resulted in novel models of toxicity, which help to explain endothelial dysfunction and cardiovascular complications that accompany genetic hemolytic anemias, malaria, blood transfusion, and atherosclerosis. The majority of models focus on nitric oxide (NO) depletion; however, in local tissue environments, $\mathrm{Hb}$ can also act as a pro-oxidant and inflammatory agent. This can alter cellular differentiation with the potential to deviate immune responses. The understanding of these mechanisms set in the context of natural scavenger and detoxification systems may accelerate the development of novel treatment strategies.
\end{abstract}

T he capability of hemoglobin $(\mathrm{Hb})$ to efficiently load and transport oxygen is inevitably linked to a broad reactivity pattern with alternative ligands, such as carbon monoxide (CO), nitric oxide (NO), hydrogen peroxide $\left(\mathrm{H}_{2} \mathrm{O}_{2}\right)$, and many others. The biochemistry of these reactions has been the focus of $\mathrm{Hb}$ research for decades. More recently, however, these $\mathrm{Hb}$ reactions were examined as a potential cause of adverse pathophysiologic processes that accompany red blood cell (RBC) destruction (i.e., hemolysis) and the accumulation of extracellular free $\mathrm{Hb}$ (Baek et al. 2012; Gladwin et al. 2012). Other biologic activities of extracellular free $\mathrm{Hb}$ can be traced back either to direct interactions of its globin or heme components with specific cellular receptors and signaling pathways, or to the secondary effects of heme breakdown by the heme oxygenases. The evolving picture suggests that $\mathrm{Hb}$ as a toxin can adversely affect the outcome of diverse conditions, including the hemolytic anemias, sepsis, malaria, blood transfusion, and atherosclerosis, in which local accumulation of extracellular $\mathrm{Hb}$ causes oxidative stress and changes macrophage polarization in the atherosclerotic plaque microenvironment. The recognition that $\mathrm{Hb}$ is a disease-modifying compound, and concurrent research on protec-

Editors: David Weatherall, Alan N. Schechter, and David G. Nathan

Additional Perspectives on Hemoglobin and Its Diseases available at www.perspectivesinmedicine.org

Copyright (C) 2013 Cold Spring Harbor Laboratory Press; all rights reserved; doi: 10.1101/cshperspect.a013433

Cite this article as Cold Spring Harb Perspect Med 2013;3:a013433 
tive $\mathrm{Hb}$ scavenger proteins have provided a framework for novel pathophysiologic models and may lead the way toward a new era of targeted treatment strategies. The toxic effects of free $\mathrm{Hb}$ appear to depend on the amounts in the extracellular space, anatomic location, and the activity of scavenger and detoxification pathways. These factors may vary considerably among different disease states and, therefore, extrapolations or application of a general $\mathrm{Hb}$ toxicity model to heterogeneous conditions must be considered cautiously. In this article we will summarize current evidence that supports $\mathrm{Hb}$ 's role as a disease modifier in hemolytic anemias, malaria, blood transfusion, and atherosclerosis, and how scavenger protein-based therapeutics could be used to attenuate the underlying pathophysiologic processes.

\section{DISEASE STATES THAT ARE MODULATED BY THE TOXICITY OF EXTRACELLULAR HEMOGLOBIN}

\section{Sickle Cell Disease and Hemoglobin-Based Oxygen Carriers}

Two areas of research, sickle cell disease (SCD), which represents a condition of chronic low-level plasma $\mathrm{Hb}$ exposure (3-10 $\mu \mathrm{m}$ plasma heme), and $\mathrm{Hb}$-based oxygen carrier (HBOC) therapy, which represents a condition of acute high-level $\mathrm{Hb}$ exposure (>500 $\mu \mathrm{M}$ plasma heme), have driven the evaluation of pathophysiologic models to better understand the roles of extracellular $\mathrm{Hb}$ toxicity as a general disease process (Buehler et al. 2010). A pronounced systemic, and in some animal models a pulmonary hypertensive, response is observed within seconds of exposure to cell-free Hb or HBOCs (Buehler et al. 2010). This acute response is likely related to the interaction of $\mathrm{Hb}$ with $\mathrm{NO}$ and is suspected to be a cause of acute myocardial infarction and stroke in certain subjects receiving HBOCs (Natanson et al. 2008; Silverman and Weiskopf 2009). HBOCs are typically transfused in large quantities reaching millimolar plasma concentrations of extracellular $\mathrm{Hb}$. These dosing levels are required to meet $\mathrm{O}_{2}$ delivery and volume replacement needs in patients with severe hemorrhage.
Sickle cell anemia is a chronic low-level hemolytic disease; however, some of the sequelae mimic those of HBOC administration. The typical complications of SCD are vasculopathies, stroke, pulmonary hypertension $(\mathrm{PH})$, and renal failure, which suggest a pathophysiology of unopposed constriction within the vasculature and, therefore, may be related to an $\mathrm{Hb}$-induced reduction in NO bioavailability. The NO depletion hypothesis is based on the findings that plasma from patients with SCD had elevated levels of free $\mathrm{Hb}$, and accordingly, that the plasma from these patients had higher ex vivo NO-depleting activity (Reiter et al. 2002). In other studies, positive correlations were found between surrogate markers of hemolysis, $\mathrm{PH}$, and disease-related mortality (Gladwin et al. 2004). PH, measured by Doppler echocardiography, was estimated to occur in up to $30 \%$ of patients with SCD and was therefore hypothesized to be a paradigmatic effect of NO depletion that could accompany chronic hemolytic diseases in general (Rother et al. 2005). The NO depletion hypothesis, however, has been challenged by other studies that found a lower, but still relevant, prevalence of $\mathrm{PH}$ when assessed by pulmonary artery catheterization (the gold standard for measuring blood pressure within the pulmonary circulation) (Parent et al. 2011). Even fewer patients in this cohort were found to have precapillary $\mathrm{PH}$, which would be expected if $\mathrm{Hb}$-mediated $\mathrm{NO}$ depletion within the pulmonary vasculature were highly relevant. Further concerns with the NO depletion hypothesis in SCD are related to the validity of hemolytic surrogate markers, such as plasma lactic acid dehydrogenase $(\mathrm{LDH})$, and to the generally low plasma $\mathrm{Hb}$ concentrations (in the low micromolar range) detected in SCD patients, even during vasoocclusive crisis, when free $\mathrm{Hb}$ concentrations remain orders of magnitude below those associated with some hyperhemolytic states or HBOC administration (Bunn et al. 2010). Other proposed mechanisms of $\mathrm{Hb}$ toxicity during SCD or HBOC administration are related to the pro-oxidative and proinflammatory properties of $\mathrm{Hb} /$ heme, which can damage the endothelium or activate components of the coagulation and innate immune systems (Jeney et al. 
2002; Belcher et al. 2003). The history of research on Hb toxicity in SCD and HBOC therapy illustrates that multiple pathways of toxicity for free $\mathrm{Hb}$ can theoretically coexist and that emphasis on one pathway may not fully define the extent and complexity of $\mathrm{Hb}$-induced pathophysiology in conditions where it may contribute to disease processes.

\section{Transfusion of Stored Blood}

RBC transfusion with acute blood loss or chronic anemia is one of the most common therapeutic interventions in medicine. Over the last two decades, however, more restrictive transfusion practices have been implemented, and transfusion thresholds have been lowered by limiting unnecessary transfusions (Barr and Bailie 2011). Accumulating evidence suggests that the adverse consequences of some transfusions are related to the storage period between blood donation and transfusion (Wang et al. 2012). The maximum allowed storage time is now $42 \mathrm{~d}$ with most storage solutions, and current blood bank practices following a "first in, first out" system that favors the distribution of older units first. A 2011 meta-analysis of retrospective data from 409,966 patients estimated that a significant (odds ratio, 1.16; 95\% confidence interval, 1.07-1.24) risk of death exists when relatively old, rather than fresh, blood is transfused. The definition of older stored blood in the analyzed studies ranged from $9 \mathrm{~d}$ up to $42 \mathrm{~d}$, with a range of 1-10 units of blood transfused per patient (Wang et al. 2012). The RBC transfusion-associated risk of death may be increased in certain high-risk populations, such as critically ill or massively transfused ( $>10$ units of blood within $24 \mathrm{~h}$ ) patients. It is important to point out that storage time-related morbidity/mortality and potential mechanisms associated with transfusion-related toxicity remains controversial and not all studies support the concept that older blood is detrimental (Middelburg et al. 2012). RBCs may undergo complex biochemical and structural changes, collectively referred to as the "RBC storage lesion." Damaged or aged RBCs can accumulate over time as a low-quality population within stored blood bags. It is there- fore possible that some degree of acute hemolysis occurs when older stored blood is transfused. Current regulations only require that $75 \%$ of transfused RBCs survive within the circulation for $24 \mathrm{~h}$ after transfusion. This means that up to $25 \%$ of RBCs may be lost within the first $24 \mathrm{~h}$ after transfusion, owing to either intravascular hemolysis or the trapping of RBCs by macrophages in the spleen or liver. In the most extreme situation, this implies an acute burden of $>10$ g extra $\mathrm{Hb}$ per unit of transfused older RBCs that are either acutely released into the circulation or metabolized by spleen and liver macrophages after erythrophagocytosis.

Small studies in healthy volunteers suggest that extravascular hemolysis and increased RBC$\mathrm{Hb}$ catabolism occur when as little as one unit of blood is transfused after 40 days of storage (Hod et al. 2011). Following single-unit transfusion, other investigators found that intravascular $\mathrm{Hb}$ exposure is associated with concomitant elevation in plasma nitrite levels and NO depletion in humans following small volume blood transfusion (Berra et al. 2012).

Animal models of RBC transfusion have been designed to explore the possible roles of intravascular hemolysis and cell-free $\mathrm{Hb}$ in the pathophysiologic consequences of the massive transfusion of older stored blood in guinea pigs (Baek et al. 2012). These studies suggest that high-volume transfusions of older blood, but not fresh blood, result in posttransfusion intravascular and extravascular hemolysis that approaches a $15 \%-20 \%$ loss of transfused RBCs within $24 \mathrm{~h}$. Transfusion of older, rather than fresh, blood caused an acute hypertensive response, hemoglobinuria, acute renal failure, and vascular injury (Fig. 1) (Baek et al. 2012). Infusion of transfused old blood with the specific $\mathrm{Hb}$ scavenger haptoglobin $(\mathrm{Hp})$ attenuated several of the transfusion-related adverse effects. These antagonist experiments proved that free $\mathrm{Hb}$ was a contributor to the observed adverse effects. Additionally, animal studies focused on the acute hemodynamic effects of stored blood have suggested that NO donors could be a therapeutic option to limit transfusion-related and hemolysis-induced pulmonary and/or systemic hypertensive responses in mice, rats, and sheep 
D.J. Schaer and P.W. Buehler

Lumenal aorta (after hemolysis)
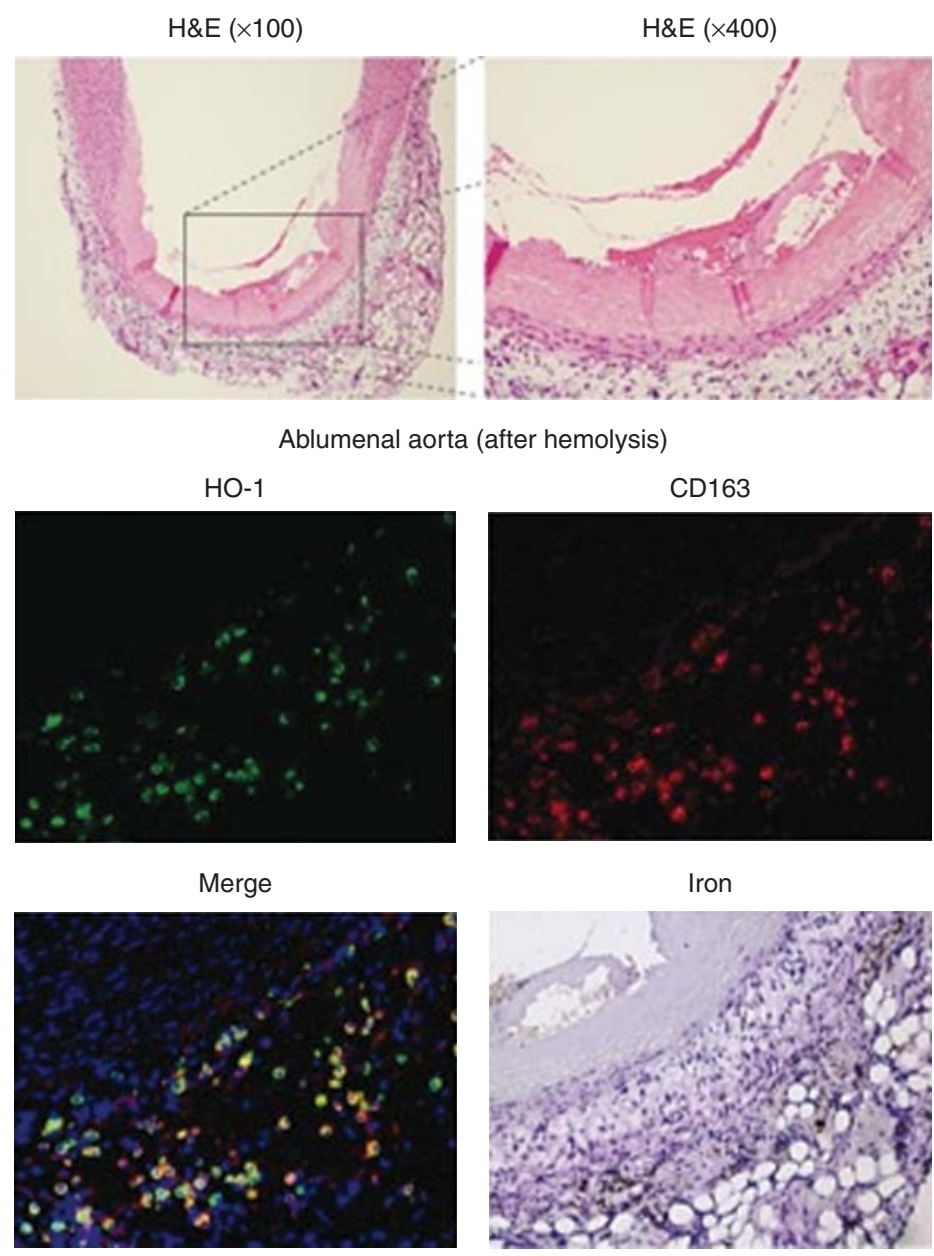

Figure 1. Vascular effects of old blood transfusion-associated hemolysis. The top panel shows regions of vascular necrosis appearing to initiate within the vascular lumen and progress to the tunica media. These observations were captured $24 \mathrm{~h}$ after massive transfusion to guinea pigs at $100 \times$ and $400 \times$ magnification. The injury in isolated regions of the aorta in transfused animals was consistent with coagulative necrosis and may be the result of hemoglobin and/or damaged red blood cells. The lower panels indicate macrophage accumulation to hemoglobin-rich regions within the adventitia consistent with HO-1, CD163, and nonheme iron accumulation.

(Yu et al. 2008, 2009, 2012; Donadee et al. 2011; Baron et al. 2012). One of these studies identified $\mathrm{Hb}$ and $\mathrm{Hb}$-containing $\mathrm{RBC}$ membrane microparticles released in vitro before transfusion as an additional factor that may enhance the adverse posttransfusion effects (Donadee et al. 2011). Blood transfusion leading to stimulation of the heme breakdown pathway and accumulation of heme catabolites was associated with anti-inflammatory and immunosup- pressive effects in multiple animal models, and such effects could contribute to the immunecompromised state of severely ill and massively transfused patients (Yazdanbakhsh et al. 2011). On the other hand, proinflammatory effects may be triggered by free heme through the stimulation of toll-like receptor 4 (TLR-4), by reaction intermediates emanating from $\mathrm{Hb} /$ heme peroxidative reactions with phospholipids, or by $\mathrm{Hb} /$ heme breakdown products 
(D'Agnillo and Alayash 2001; Jeney et al. 2002; Jia et al. 2007; Lin et al. 2010; Yazdanbakhsh et al. 2011). In a mouse blood transfusion model, older stored RBCs induced an acute phase cytokine release response that accompanied the clearance of transfused RBCs in the spleen (Hod et al. 2010).

In summary, intravascular release and enhanced turnover of $\mathrm{Hb}$ after transfusion of older stored blood could contribute to cardiovascular and renal dysfunction, as well as inflammation and enhanced susceptibility to infection in severely ill patients. However, similar to interpretation of retrospective human data, the translation of animal-based transfusion model data to the human situation is nearly impossible. In animal studies, RBCs are often maximally stressed and RBCs of animals and humans behave with varying degrees of difference both under storage and following transfusion. As a result it is unlikely that any model will provide a definitive understanding of the potential complications associated with human blood storage. The best that animal studies can be expected to provide are suggestions for pathophysiologic mechanisms that may help to explain poor outcomes previously reported in clinical settings.

\section{Malaria}

Malaria is a paradigmatic hemolytic condition and considered a driving force in human evolution. Several common hemoglobinopathies, such as SCD or the thalassemias, have been proposed to result, in part, from the coevolutionary interactions between the plasmodium parasite and its human host (Rosenthal 2011). Animal studies in mice have been used to construct hypothetic models of the pathophysiologic role of the $\mathrm{Hb}$ molecule in malarial disease progression and tolerance. In the acute phase of severe malaria, hemolysis appears to exaggerate inflammatory processes and endothelial damage through NO depletion, oxidation, and inflammation (Gramaglia et al. 2006; Pamplona et al. 2007). The appearance of $\mathrm{Hb}$ and heme in plasma has been linked to the development of cerebral malaria, which remains the most severe and difficult to treat complication of the infec- tion. In contrast, chronic hemolysis (before malaria infection) in SCD induces a state of malaria tolerance by enhancing the basal activity of heme defense systems, such as heme oxygenase 1 (HO-1) up-regulation, which drives the generation of metabolites with anti-inflammatory effects (i.e., CO, bilirubin, and ferritin) (Ferreira et al. 2011). Thus, active hemolysis before infection does not alter the course of parasitemia per se, but may prevent progression to fatal disease complications. However, similar mechanisms that confer a state of relative tolerance to severe malaria may also enhance host susceptibility to concurrent nonplasmodium infections. Infection with nontyphoid Salmonella during the acute hemolytic phase of plasmodium infection was associated with the appearance of an immature granulocyte population with reduced oxidative burst capacity and, consequently, a reduced capacity to kill phagocytosed Salmonella (Cunnington et al. 2011). This effect was mimicked experimentally by heme injection and attenuated when HO-1 was inhibited. As a result, animals that were coinfected with malaria were much more susceptible to fatal Salmonella infection than control animals that were not heme stressed.

It is overly simplistic to reduce the pathophysiology of a complex parasite infection with diverse host-pathogen interaction pathways to the level of the $\mathrm{Hb}$ molecule as a single mechanism of pathology. However, based on the discussed animal studies, the impact of hemolysis in malaria could be a relevant component. Lowlevel hemolysis before plasmodium infection may induce a state of tolerance, attenuating the deleterious effects of $\mathrm{Hb} /$ heme in the acute phase. Acute $\mathrm{Hb}$ and heme exposure exaggerate inflammatory and oxidative tissue damage in nontolerant individuals and may enhance susceptibility to superinfection by nonmalaria pathogens. An important lesson to take away from these studies is that $\mathrm{Hb}$ and heme may have diverse pathophysiology in patients with inflammatory diseases and infection. The net impact of extracellular $\mathrm{Hb}$ in a given disease state can be protective or deleterious, and the effect is likely determined by the anatomic site, timing, and degree of hemolysis on one hand, and availability of scavenger systems on the other hand. 


\section{Atherosclerosis-A Paradigm for $\mathrm{Hb}$ as a Locally Active Disease Modifier}

As exemplified in the sections above, the pathophysiology of extracellular $\mathrm{Hb}$ has largely been studied on a systemic level. It is likely, however, that $\mathrm{Hb}$ also acts as an important modulator of local disease processes, where RBCs extravasate and are lysed within tissues. Under such conditions, very high extracellular concentrations of $\mathrm{Hb}$ and heme (in the millimolar range) could affect cell viability, activation state, and differentiation (Boyle et al. 2009).

One of the paradigmatic conditions in which local $\mathrm{Hb} /$ heme effects have been studied is atherosclerosis. The principal findings of these investigations may similarly apply to other clinical situations, such as wound healing or hemorrhagic stroke. Microscopic hemorrhage from fragile neovessels is a hallmark of advanced plaques, and a predictor of catastrophic clinical events such as myocardial infarction and stroke (Kolodgie et al. 2003). Besides the cholesterol and phospholipid-rich RBC membrane components that are deposited in the areas of microbleeding, $\mathrm{Hb}$ is the most abundant and biologically reactive compound within these lesions (Schaer et al. 2006).

The potential effects of $\mathrm{Hb}$ are diverse. Heme can oxidize low-density lipoprotein (LDL) and other lipids, and transform these compounds into proinflammatory and cytotoxic species (e.g., oxidized LDL) that have an established impact on atherosclerotic plaque progression (Nagy et al. 2010). Hb-derived free heme, as well as heme- and globin-degradation products, have a cytotoxic impact on endothelial and vascular smooth muscle cells, and may act as proinflammatory mediators that perpetuate inflammatory cell recruitment through the stimulation of chemokine (e.g., IL-8) expression (Boyle et al. 2009; Kaempfer et al. 2011). Free $\mathrm{Hb}$ in the extracellular environment may also polarize the differentiation plasticity of certain cell types. The observation that phenotypically distinct macrophage subpopulations cluster within hemorrhagic and nonhemorrhagic plaque areas has stimulated research exploring whether $\mathrm{Hb}$ and/or heme are the factors reshap- ing monocyte-macrophage lineage differentiation in these lesions (Boyle et al. 2009).

The specific interest in macrophages is twofold. On the one hand, macrophages are the principal inflammatory cell type within atherosclerotic plaques, and primary mediators of disease progression. On the other hand, they are the only cell type that expresses the $\mathrm{Hb}$ scavenger receptor CD163, and possess a highly specialized physiology to handle and detoxify extracellular $\mathrm{Hb}$. Because of this unique function, macrophages in $\mathrm{Hb}$-rich environments have very high expression levels of HO-1, ferritin, and the iron exporter ferroportin. In vitro and in the coronary arteries of patients, $\mathrm{Hb} /$ heme-exposed macrophages were described as a distinct phenotype with high expression of the $\mathrm{Hb}$ detoxification pathway (CD163 ${ }^{\text {high }}$ HO- $\left.1^{\text {high }}\right)$, high mannose receptor expression, and profoundly suppressed expression of HLA class 2 (Boyle et al. 2009; Kaempfer et al. 2011; Finn et al. 2012). This nonfoamy macrophage subtype localizes to the postbleeding plaque areas, has enhanced antioxidative and iron export functions, and is resistant to cholesterol loading as a result of up-regulated ATP-binding cassette transporters (ABCA1 and ABCG1) and down-regulated scavenger receptors (SR-A/B and CD36). The available data suggest that these $\mathrm{Hb} /$ heme-driven macrophages constitute a unique phenotype (referred to as M-hem or $\mathrm{M}-\mathrm{Hb}$ ), with distinct and nonoverlapping features, within the known spectrum of macrophage phenotypes extending from proinflammatory (M1) to anti-inflammatory (M2) macrophages. The $\mathrm{Hb} /$ heme-driven macrophage phenotype polarization appears to be triggered by increased intracellular heme levels via a pathway involving signaling by Nrf-2 and the activating transcription factor 1 (ATF1), with subsequent coinduction of $\mathrm{HO}-1$ and liver-Xreceptor $\beta$ (LXR $\beta$ ) (Kaempfer et al. 2011; Boyle et al. 2012). The functional significance of the profoundly suppressed levels of HLA class 2 in these macrophages has not been evaluated, but the spectrum of functional consequences of this intriguing $\mathrm{Hb} /$ heme-induced condition may include enhanced control of autoimmunity and/or increased susceptibility to infection. 
Accumulating evidence now suggests that $\mathrm{Hb} /$ heme can impact multiple levels of innate and acquired immunity. Hb should therefore be considered a novel intrinsic alarm molecule that serves to signal bleeding and tissue destruction.

In summary, $\mathrm{Hb}$ may play a dual role in atherosclerosis. The proinflammatory and oxidative effects of heme within the extracellular milieu initiate and promote plaque formation, whereas $\mathrm{Hb}$ /heme drives macrophage polarization toward a protective, nonfoamy, and antioxidative macrophage phenotype that halts lesion progression at later stages of the disease. It remains to be explored how these opposing processes could be shifted favorably by pharmacological interventions.

\section{MECHANISMS OF HEMOGLOBIN- MEDIATED ADVERSE EFFECTS}

The primary acute pathophysiologic responses to extracellular $\mathrm{Hb}$ in plasma are blood pressure elevation (Rother et al. 2005) and pro-oxidative toxicity occurring in vascular and renal tissues (Boretti et al. 2009; Baek et al. 2012). The processes driving $\mathrm{Hb}$-induced toxicity are depicted in Figure 2 and likely involve a complex interaction between NO balance, oxidation, and inflammation.

\section{Nitric Oxide Consumption - Systemic and $\mathrm{PH}$}

The most accepted hypothesis for $\mathrm{Hb}$-induced hypertension involves the interactions of $\mathrm{NO}$ with both oxy- and deoxyhemoglobin (Doherty et al. 1998; Olson et al. 2004). The pathophysiologic response to $\mathrm{Hb}$ and its consumption of $\mathrm{NO}$ is observed primarily as an increase in systolic/diastolic and mean arterial blood pressure (MAP) with cardiac output either unchanged (Boretti et al. 2009) or decreased (Minneci et al. 2005). This consistently causes an increase in systemic vascular resistance, or vasoconstriction (Reiter et al. 2002; Minneci et al. 2005; Boretti et al. 2009). In addition, heart rate and stroke volume are often deceased with the aggregate hemodynamic response resulting in decreased perfusion to some organ systems, particularly the kidneys.
Following infusion of a bolus of $\mathrm{Hb}$ into the vascular space, the MAP response appears to be related to the pharmacokinetics of the protein in circulation (Fig. 3), with rapid blood pressure normalization and parallel renal clearance of free $\mathrm{Hb}$. However, in animal models of $\mathrm{RBC}$ transfusion-related hemolysis and cases in which an HBOC with a long intravascular circulatory time is administered, there is a clear disconnect between pharmacodynamics (blood pressure response and duration) and pharmacokinetics (maximal concentration and total exposure) (Buehler et al. 2007). This suggests that some degree of tolerance to extracellular $\mathrm{Hb}$ in circulation occurs with longer-term exposures. If analyses of $\mathrm{Hb}$-mediated vascular wall injury are considered, however, the duration of sustained intravascular $\mathrm{Hb}$ exposure appears to be a critical determinant of the cumulative toxicity (Baek et al. 2012).

Within the context of potential pathology, $\mathrm{Hb}$ access to $\mathrm{NO}$ progresses via two primary reactions: (1) NO dioxygenation, and (2) iron nitrosylation of NO deoxy-Hb:

(1) $\mathrm{Hb}_{-} \mathrm{Fe}^{2+}\left(\mathrm{O}_{2}\right)+\mathrm{NO} \rightarrow\left\{\mathrm{Hb}\left(\mathrm{Fe}^{3+} \mathrm{OONO}^{\bullet}\right)\right\}$

$$
\rightarrow \mathrm{Hb}-\mathrm{Fe}^{3+}+\mathrm{NO}_{3}^{-} \text {, }
$$

$$
\mathrm{Hb}-\mathrm{Fe}^{2+}+\mathrm{NO} \rightarrow \mathrm{Hb}(\mathrm{NO}) .
$$

Our understanding of the factors controlling these processes is largely owing to the extensive study of HBOCs and their effects on systemic and pulmonary hemodynamics (Doherty et al. 1998; Olson et al. 2004). Targeted mutagenesis to limit interactions with NO or chemical modification of human $\mathrm{Hb}$ attenuated the systemic vascular response, presumably via reduced $\mathrm{NO}$ consumption within sites of $\mathrm{NO}$ generation or decreased access to sites of NO production. $\mathrm{Hb}$ exposure also stimulates other vasoconstrictive physiologic systems and effectors such as angiotensin, endothelin, and prostaglandins (Buehler et al. 2010).

Pulmonary arterial pressure (PAP) is regulated by $\mathrm{NO}$, prostacyclin, endothelin, as well as thromboxane; several of these regulators have been studied in association with $\mathrm{Hb}$ (Heller et al. 1998; Farber and Loscalzo 2004; Yu et al. 2009). The primary cause for PAP elevation 
D.J. Schaer and P.W. Buehler

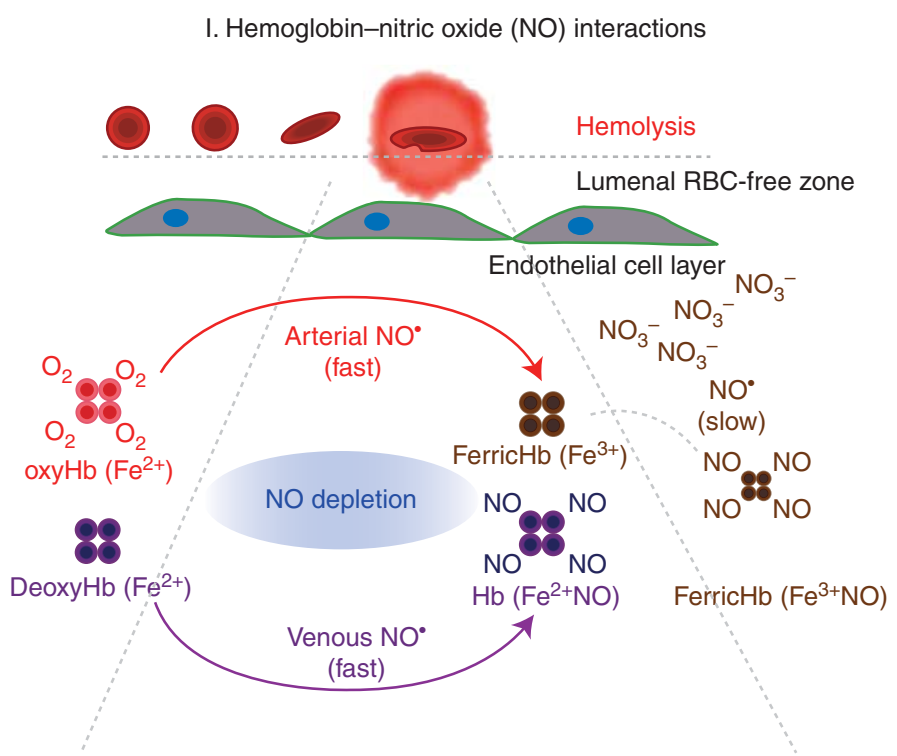

II. Hemoglobin peroxidation
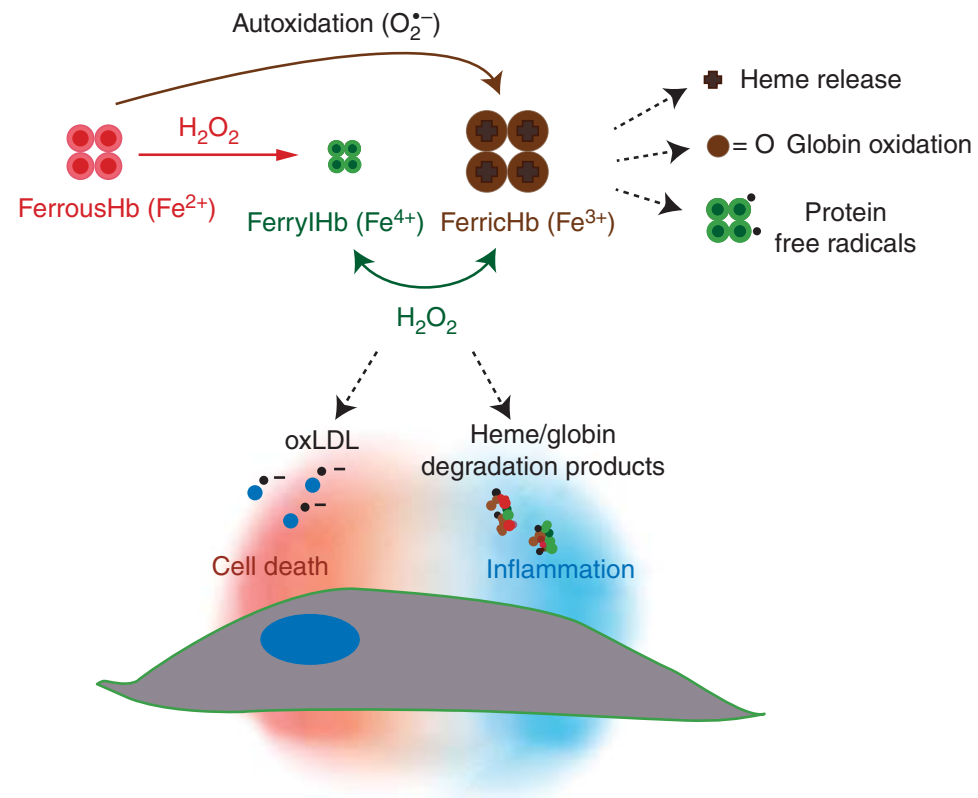

Figure 2. Schematic of hemoglobin-mediated toxicity initiated by intravascular hemolysis. (I) NO reactions with hemoglobin-Red blood cells (RBC) do not enter the vascular luminal RBC-free zone; however, free hemoglobin can enter the RBC-free zone and gain access to endothelial and perivascular spaces. When free oxyhemoglobin (red) enters the perivascular space it can react with $\mathrm{NO}$ rapidly via dioxygenation forming ferric hemoglobin (brown) and nitrate $\left(\mathrm{NO}_{3}^{-}\right)$. Additionally, deoxyhemoglobin (purple) can react with $\mathrm{NO}$ to form iron nitrosyl hemoglobin. Additionally, ferric hemoglobin can react with NO, but at much slower rates. It remains unknown whether this reaction is of any biologic significance. (II) Hemoglobin peroxidative reactions-Oxyhemoglobin (red) undergoes peroxidation to ferryl hemoglobin (green) followed by a redox cycle that is driven by hydrogen peroxide. (Legend continues on following page.) 
induced by extracellular $\mathrm{Hb}$ has also been attributed to NO consumption. Elevated pulmonary vascular resistance was shown in dogs (Minneci et al. 2005) and PH was shown in rodents and sheep following exposure to $\mathrm{Hb}$ (Yu et al. 2008). These studies suggest a causal relationship between $\mathrm{Hb}$ and NO, based on the use of NO synthase inhibitors and reversal of $\mathrm{PH}$ via $\mathrm{NO}$ supplementation before $\mathrm{Hb}$ exposure. In other acute $\mathrm{Hb}$ exposures, such as transfusion-related hemolysis, $\mathrm{PH}$ is reported to occur more readily in animals with endothelial dysfunction compared with normal animals (Yu et al. 2012). Pretransfusion NO inhalation was shown to attenuate this pathology (Baron et al. 2012). Certain animal species show $\mathrm{PH}$ in response to HBOCs; however, it is unknown whether this effect regularly occurs following HBOC infusion in humans and whether a short-term increase in PAP could contribute to adverse events following extracellular $\mathrm{Hb}$ exposure or HBOC administration. Publicly available data on the incidence of $\mathrm{PH}$ from $\mathrm{HBOC}$ clinical trials show one event among 504 subjects treated with diaspirin-crosslinked $\mathrm{Hb}$ (DCLHb, HemAssist) (no events among 505 control subjects) and three events among 708 subjects treated with HBOC-201 (no events among 618 control subjects). It is unknown whether subjects who experienced acute transient PAP elevation developed clinically relevant events.

\section{In Vivo Oxidation of Hemoglobin}

Hydrogen peroxide and lipid hydroperoxides in tissue compartments are important components influencing the oxidative toxicity of heme proteins (Moore et al. 1998). Intracellular hydrogen peroxide $\left(\mathrm{H}_{2} \mathrm{O}_{2}\right)$ is generated by the dismutation of superoxide $\left(\mathrm{O}_{2}^{\bullet-}\right)$, either spon- taneously or by superoxide dismutase, and is involved in cellular signaling. Its primary fate is intracellular conversion to $\mathrm{H}_{2} \mathrm{O}$ and $\mathrm{O}_{2}$ by catalases and peroxidases. The remaining $\mathrm{H}_{2} \mathrm{O}_{2}$ can be converted to reactive oxygen species or secreted into the extracellular environment, typically in low $(1-15 \mu \mathrm{M})$ quantities (D’Agnillo et al. 2001). During inflammation, certain cell types, such as granulocytes and macrophages, increase the production and release of $\mathrm{H}_{2} \mathrm{O}_{2}$. The production, from $\mathrm{H}_{2} \mathrm{O}_{2}$ and chloride $\left(\mathrm{Cl}^{-}\right)$, and secretion of hypochlorous acid are also increased. The increased levels of pro-oxidants could interact with extracellular $\mathrm{Hb}$ within localized tissue compartments and certain vascular sites. The reactions of $\mathrm{Hb}$ with peroxides have been extensively studied under "testtube" conditions, and can be summarized as follows: Deoxy-Hb reacts with $\mathrm{H}_{2} \mathrm{O}_{2}$ via the following steps: (1) oxo-ferryl $\mathrm{Hb}\left[\mathrm{Hb}\left(\mathrm{Fe}^{4+}=\right.\right.$ $\mathrm{O})]$ generation, (2) ferric $\mathrm{Hb}\left[\mathrm{Hb}\left(\mathrm{Fe}^{3+}\right)\right]$ generation, and (3) protein radical generation $\left[{ }^{\bullet} \mathrm{Hb}\left(\mathrm{Fe}^{4+}=\mathrm{O}\right)\right]$.

$$
\begin{aligned}
& \mathrm{Hb}\left(\mathrm{Fe}^{2+}\right)+\mathrm{H}_{2} \mathrm{O}_{2} \rightarrow \mathrm{Hb}\left(\mathrm{Fe}^{4+}=\mathrm{O}\right) \\
& +\mathrm{H}_{2} \mathrm{O} \text {, } \\
& \mathrm{Hb}\left(\mathrm{Fe}^{4+}=\mathrm{O}\right)+\mathrm{H}^{+} \rightarrow \mathrm{Hb}\left(\mathrm{Fe}^{3+}\right) \mathrm{OH}^{-}
\end{aligned}
$$

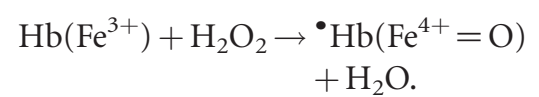

Ultimately, the globin chain-free radical shown in reaction (3) is available to participate in localized amino acid oxidations (e.g., within $\mathrm{Hb}$ ) or transfer to LDL (Miller et al. 1997; Vallelian et al. 2008; Pimenova et al. 2010). Peroxidative $\mathrm{Hb}$ reactions with production of ferryl $\mathrm{Hb}$ and free radicals have been considered an important component of $\mathrm{Hb}$ and $\mathrm{HBOC}$ toxicity in the past (Alayash 2004). However, despite

Figure 2. (Continued) In the presence of large quantities of reducing agents ferryl stability in this reaction is reduced to an extent that the species cannot accumulate, and in most cases cannot be directly detected. The most prevalent oxidized $\mathrm{Hb}$ species in vivo is therefore ferric $\mathrm{Hb}$, which can result from peroxidation but also from autoxidation and $\mathrm{NO}$ dioxygenation depicted above. In vitro, the result of redox cycling mediated by $\mathrm{H}_{2} \mathrm{O}_{2}$ can be release of heme, globin chain radicals, and oxidation of amino acids within the hemoglobin molecule. The protein may also degrade to precipitate formed by globin-heme adducts and cross-links that physically damage endothelial cells leading to inflammation. Additionally, free radical transfer from ferryl radical oxidizes lipid, leading to potential tissue oxidation as well as inflammation. 
D.J. Schaer and P.W. Buehler
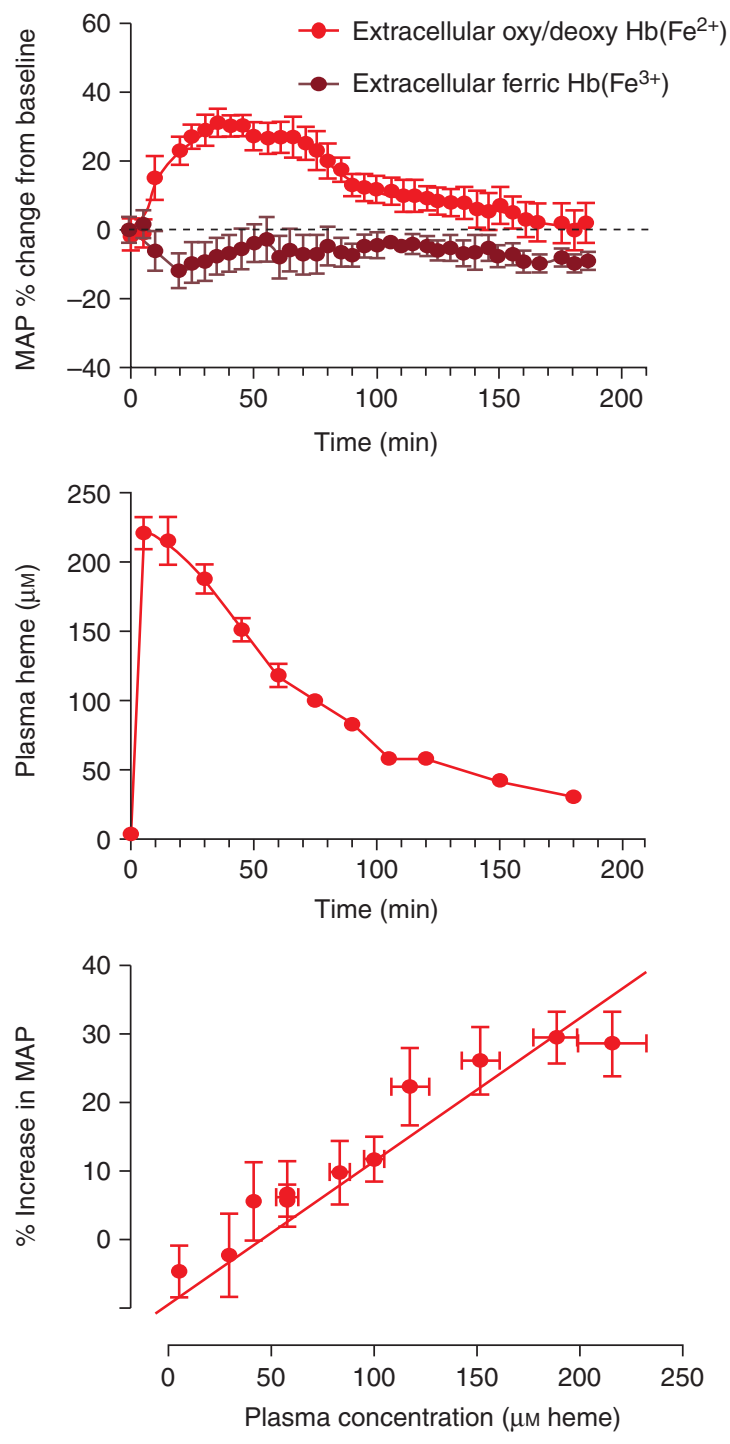

Figure 3. Plasma concentration blood pressure relationships. (Top) The blood pressure response to ferrous (red) and ferric (brown) hemoglobin following a $20 \%$ top load to conscious guinea pigs. Ferric hemoglobin shows no response, whereas ferrous hemoglobin shows a rapid and transient increase in mean arterial pressure. This is consistent with the hemoglobin plasma concentration time course shown (middle). These two time effects can be better visualized by plotting plasma concentration versus percent mean arterial blood pressure change from baseline (bottom).

the extensive biochemical knowledge of oxidative $\mathrm{Hb}$ reactions in vitro, it is far less clear to what extent these reactions do occur in vivo and how they could contribute to $\mathrm{Hb}$ toxicity. For example, it is not consistently possible to trap ferryl $\mathrm{Hb}$ or $\mathrm{Hb}$-associated free radicals in vivo. An explanation for this discrepancy might be that the reactions occur in vivo in a complex environment with different oxidants and in the presence of large quantities of reductants (e.g., ascorbate, urate, and enzymatic reductants). These conditions likely prevent ferryl $\mathrm{Hb}$ accumulation above a certain threshold of detection. In vivo evidence for these oxidative 
$\mathrm{Hb}$ processes is therefore largely based on indirect markers such as intramolecular $\mathrm{Hb}$ crosslinks and globin amino acid oxidations that have been detected in some studies (Moore et al. 1998; Boutaud et al. 2010).

The kidneys are heavily exposed to heme and globin components owing to the extensive and rapid filtration of extracellular $\mathrm{Hb}$. The mechanism of $\mathrm{Hb}$ toxicity in the kidneys may be related to redox cycling and ferryl $\mathrm{Hb}$ formation (Zager and Gamelin 1989; Moore et al. 1998; Boutaud et al. 2010). During rhabdomyolysis, redox cycling of ferric and ferryl myoglobin, driven by lipid hydroperoxides, enhances tissue oxidation and $\mathrm{F}_{2}$-isoprostane release (Moore et al. 1998; Boutaud et al. 2010). Observations of the excretion of covalently crosslinked dimeric, tetrameric, and polymeric $\mathrm{Hb}$, as well as iron deposition and oxidative tissue modifications, in the kidneys of $\mathrm{Hb}$-infused animals were interpreted as indicators of the peroxidative activity of $\mathrm{Hb}$ in vivo (Boretti et al. 2009; Butt et al. 2010). Within the gastrointestinal circulation of rats, an increase in microvascular permeability to fluorescently labeled albumin was reported to occur with several HBOCs (Baldwin et al. 2002). These effects appeared to be causally linked to the rates of oxidation of the individual HBOCs (Baldwin et al. 2002). Coadministration of the antioxidant sodium selenite reduced mesenteric vascular leakage and mucosal epithelial damage (Baldwin et al. 2003).

\section{PHYSIOLOGIC HEMOGLOBIN SCAVENGERS, ANTIOXIDANTS, AND DETOXIFICATION SYSTEMS}

The $\mathrm{Hb}$ scavenger system is a multiple-component pathway made up of several soluble plasma proteins (e.g., haptoglobin [Hp], hemopexin [Hpx], $\alpha 1$-microglobulin, and albumin) (Schaer and Alayash 2012). Cell-based receptors bind the $\mathrm{Hb}$, or heme complexes of these proteins, and protect against systemic $\mathrm{Hb}$ and heme toxicity, until heme is degraded to metabolites by the heme oxygenases. The most extensively studied pathways are those involving the plasma $\mathrm{Hb}$ scavenger $\mathrm{Hp}$ and the monocyte/macro- phage $\mathrm{Hb}-\mathrm{Hp}$ scavenger receptor CD163 (Kristiansen et al. 2001; Schaer et al. 2006b). Additionally, the plasma heme-binding protein $\mathrm{Hpx}$ and its interaction with the LDL receptor-related protein 1 (LRP-1) appear to be critical when heme is released from $\mathrm{Hb}$ and other proteins (Nielsen et al. 2010). Hp remains the most important plasma $\mathrm{Hb}$-binding protein, whereas the role of Hpx is secondary and generally required only when heme is released from $\mathrm{Hb}$ following oxidation. Figure 4 depicts the process of $\mathrm{Hb} /$ heme clearance and iron recycling within the plasma, macrophages, and erythroid cellular compartments.

\section{Haptoglobin}

The primary Hb scavenger in plasma is Hp (Levy et al. 2010). Each $\mathrm{Hp} \beta$ chain binds one $\mathrm{Hb} \alpha \beta$ dimer in a 1:1 stoichiometry. In mammalian species, the primary phenotype of $\mathrm{Hp}$ is $1-1$, meaning that the protein contains two identical $\beta$ chains and two $\alpha 1$ chains assembled as $\beta \alpha 1-\alpha 1 \beta$ (90 kDa). The disulfide bond between the $\alpha 1$ chains occurs at only one cysteine residue. In humans, certain evolutionary changes have driven the expression of two additional phenotypes, Hp 2-1 and Hp 2-2, in which the $\alpha 2$ chain has two exposed cysteine residues available for disulfide bonding (Wicher and Fries 2010). Hp 2-1 contains an $\alpha 2$ chain, two $\alpha 1$ chains, and three $\beta$ chains (135 kDa). Hp 22 contains only $\alpha 2$ chains and $\beta$ chains that can form a multitude of self-polymerizing proteins with a molecular mass ranging from $\sim 135 \mathrm{kDa}$ to $800 \mathrm{kDa}$. Additional mutations exist in humans, but remain rare and isolated. The formation of $\mathrm{Hb}-\mathrm{Hp}$ creates a stable and irreversible complex that circulates in the plasma until it is cleared by CD163-expressing peripheral blood monocytes or tissue-resident macrophages (Kristiansen et al. 2001).

\section{Hemopexin}

This protein is primarily expressed in the liver and, like $\mathrm{Hp}$, is classified as a class I acute phase protein induced by proinflammatory cytokines (i.e., IL-1 and IL-6) (Tolosano et al. 1999, 2010). 


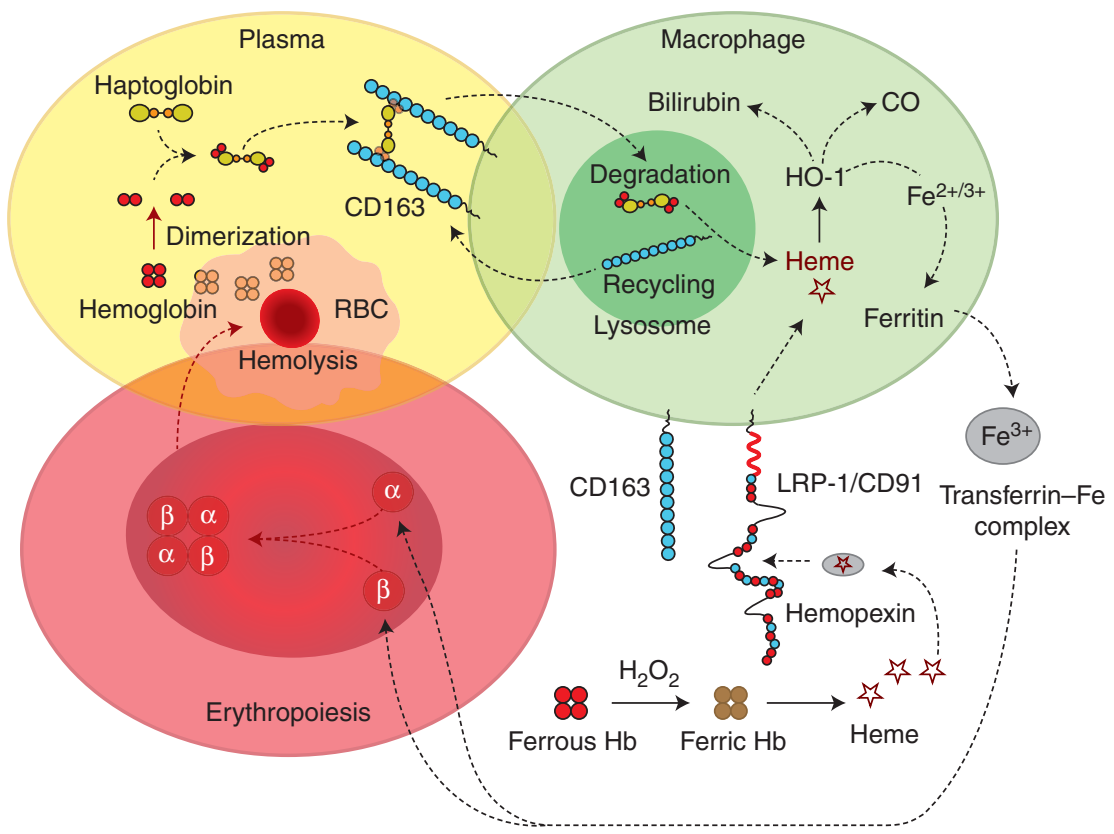

Figure 4. Physiologic hemoglobin scavengers and detoxification systems. Hb can be released from red blood cells (RBC) into the plasma and extracellular environment during hemolysis or tissue injury. In the extracellular compartment, $\mathrm{Hb}$ reacts with peroxides $\left(\mathrm{H}_{2} \mathrm{O}_{2}\right.$ and lipid hydroperoxides $)$ and promotes oxidative tissue damage. In the plasma or extracellular space, $\mathrm{Hb}$ is sequestered in the $\mathrm{Hb}-\mathrm{Hp}$ complex. Complex formation prevents $\mathrm{Hb}$-induced hypertensive and oxidative reactions. The $\mathrm{Hb}-\mathrm{Hp}$ complex is subsequently endocytosed by the macrophage $\mathrm{Hb}$ scavenger receptor $\mathrm{CD} 163$. Within the macrophage, heme is released from globin and degraded by $\mathrm{HO}-1$ into bilirubin and carbon monoxide $(\mathrm{CO})$. The released iron induces ferritin synthesis. Iron can either be exported for iron recycling or it can be stored in a ferritin complex. Backup systems such as hemopexin ( $\mathrm{Hpx})$ and the $\mathrm{Hpx}$-heme complex receptor (LDL receptor-related protein, LRP) pathway can bind and detoxify free heme that is released from oxidized $\mathrm{Hb}$.

The interaction of free heme with Hpx is reported to be the strongest plasma heme-protein interaction with a $K_{\mathrm{d}}<10^{-13} \mathrm{M}$ (Tolosano et al. 2010). Following inflammation, Hpx is synthesized in the liver, generating mean plasma concentrations of $\sim 10 \mu \mathrm{M}(0.6 \mathrm{mg} / \mathrm{mL})$ (Tolosano et al. 1999, 2010). In sickle cell anemia and thalassemia, Hpx is typically depleted in the plasma. Once heme-Hpx binding occurs, interaction and uptake by the macrophage-associated LRP-1 receptor removes the heme from the circulation (Nielsen et al. 2010).

\section{Monocyte/Macrophage CD163}

In the circulation and tissues, the $\mathrm{Hb}-\mathrm{Hp}$ complex is cleared by the $\mathrm{Hb}$ scavenger receptor CD163, a 130-kDa scavenger receptor teth- ered to peripheral blood monocytes/macrophages and tissue-resident macrophages (Kristiansen et al. 2001; Schaer et al. 2006b, 2007). $\mathrm{CD} 163$ is the primary receptor responsible for removing free $\mathrm{Hb}$ (primarily as $\mathrm{Hb}-\mathrm{Hp}$ ) from the circulation. The binding of the $\mathrm{Hb}-\mathrm{Hp}$ complex to the scavenger receptor cysteinerich domain three of CD163 and its subsequent uncoupling following uptake are calcium-dependent. CD163 is cleaved from monocyte and macrophage cell surfaces by a TNF- $\alpha$-converting enzyme/A Disintigrin and Metalloproteinase 17 mechanism under conditions of inflammation (Etzerodt et al. 2010). The inflammation-linked cleavage and plasma levels of CD163 have been shown to be elevated during general tissue inflammation; the highest concentrations were found in patients with 
macrophage-activation syndromes (Schaer et al. 2005).

Endocytosis of the $\mathrm{Hb}-\mathrm{Hp}$ complex results in cellular delivery of heme and up-regulation of HO-1. This provides a link to enhanced macrophage HO-1 clearance of heme (Schaer et al. 2006a; Vallelian et al. 2010). The end result of this process is the up-regulation of the synthesis of heme metabolites (i.e., bilirubin, $\mathrm{CO}$, and ferritin) that may function as antioxidants (bilirubin and ferritin) and signaling molecules (CO) (Otterbein et al. 2003).

\section{Hemoxygenase}

The loss of heme oxygenase (HO) function, or HO-1 deficiency, in humans was first reported in 1999 (Yachie et al. 1999). The disease was described in a 6-yr-old boy, who suffered from severe growth retardation, increased RBC fragility, chronic hemolysis with paradoxically elevated Hp levels, elevated ferritin levels, iron deposition in renal and hepatic tissues, and marked kidney injury (Yachie et al. 1999). This very rare condition provided important insight into the functional role and importance of this class of enzymes. HO is the primary enzyme of heme catabolism. Two predominant isoforms are involved in heme metabolism, HO-1 and HO-2, and both enzymatically degrade heme to biliverdin, bilirubin, iron, and CO (Abraham and Kappas 2008). HO-2 is constitutively expressed; however, HO-1 is induced by various stimuli including heme, lipopolysaccharide, hypoxia, and heavy metals (Abraham and Kappas 2008). However, heme is the most potent physiologic inducer of HO-1 (Balla et al. 1993). Although it appears evident that HOs are essential to keep intracellular heme homeostasis within a physiologic (e.g., nontoxic range), many effects that are associated with under- or overexpression of these enzymes are poorly understood. For example, the mechanisms and pathways of cellular heme toxicity (e.g., in cases of inappropriately low HO-1 expression or excessive heme load) have not yet been systematically explored. Cellular heme toxicity is mostly considered to be caused by nonspecific oxidative reactions that may damage cellular proteins and lipid compo- nents. However, it is likely that more complex pharmacologic effects of the protoporphyrin exist and could disturb essential metabolic pathways. Likewise, it is uncertain to what extent the protection against heme toxicity by $\mathrm{HO}$ is dependent on biologic activities of its metabolic end products ( $\mathrm{CO}$, iron, and bilirubin) in addition to the primary catabolic heme "removal" activity (Otterbein et al. 2003).

\section{SCAVENGER PROTEIN-BASED THERAPEUTICS FOR HEMOLYTIC CONDITIONS}

Several studies have explored the protective activities of $\mathrm{Hp}$ and $\mathrm{Hpx}$ against $\mathrm{Hb} /$ heme-driven disease processes in vitro and in vivo, and novel therapeutics based on these proteins have been proposed. Hp can prevent heme release from met- $\mathrm{Hb}\left(\mathrm{Fe}^{3+}\right)$ and, in the presence of $\mathrm{H}_{2} \mathrm{O}_{2}$, attenuate the peroxidation of globin chain amino acids and the oxidative modification of external molecules (i.e., other proteins and lipids) (Miller et al. 1997; Buehler et al. 2009; Pimenova et al. 2010). These protective functions appear to be related to the ability of Hp to firmly stabilize the structure of the bound $\mathrm{Hb} \alpha \beta$ dimers, and to a less understood mechanism whereby $\mathrm{Hp}$ shields peroxidative reactions within the $\mathrm{Hb}-\mathrm{Hp}$ complex from external substrates. The $\mathrm{Hb}-\mathrm{Hp}$ complex can still react with many ligands such as $\mathrm{O}_{2}, \mathrm{NO}, \mathrm{H}_{2} \mathrm{O}_{2}$, and nitrite (Boretti et al. 2009; Buehler et al. 2009; Roche et al. 2012). It is unknown whether these reactions have any biological function. Some hypotheses suggest that the $\mathrm{H}_{2} \mathrm{O}_{2}$ reaction may attenuate oxidative stress in inflamed tissues, whereas the enhanced nitrite-reductase activity of the complex may help to control the adverse vascular effects of unopposed NO consumption within the circulation. Another essential function of $\mathrm{Hp}$ in vivo is the capture of the relatively small $\mathrm{Hb}$ dimers within the circulation by a protein complex too large for renal clearance and extravasation (Boretti et al. 2009; Baek et al. 2012). This intravascular sequestration limits toxic $\mathrm{Hb}$ exposure in the kidneys and other sensitive tissues, and may also prevent access of the NO scavenger $\mathrm{Hb}$ to the vascular wall (Fig. 5). Proof of concept 
D.J. Schaer and P.W. Buehler

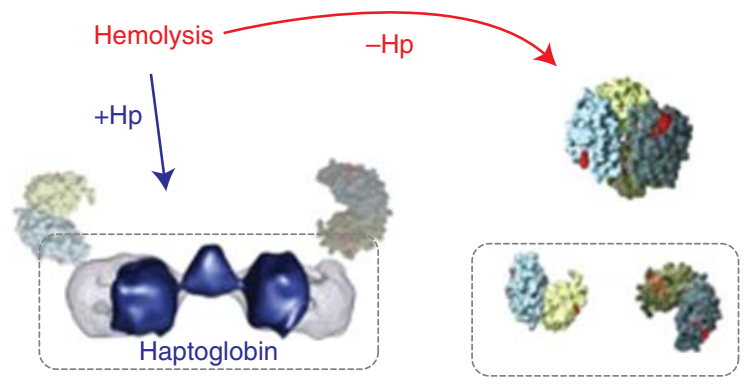

$\mathrm{Hb}:$ Hp complex

Dissociated $\mathrm{Hb}$

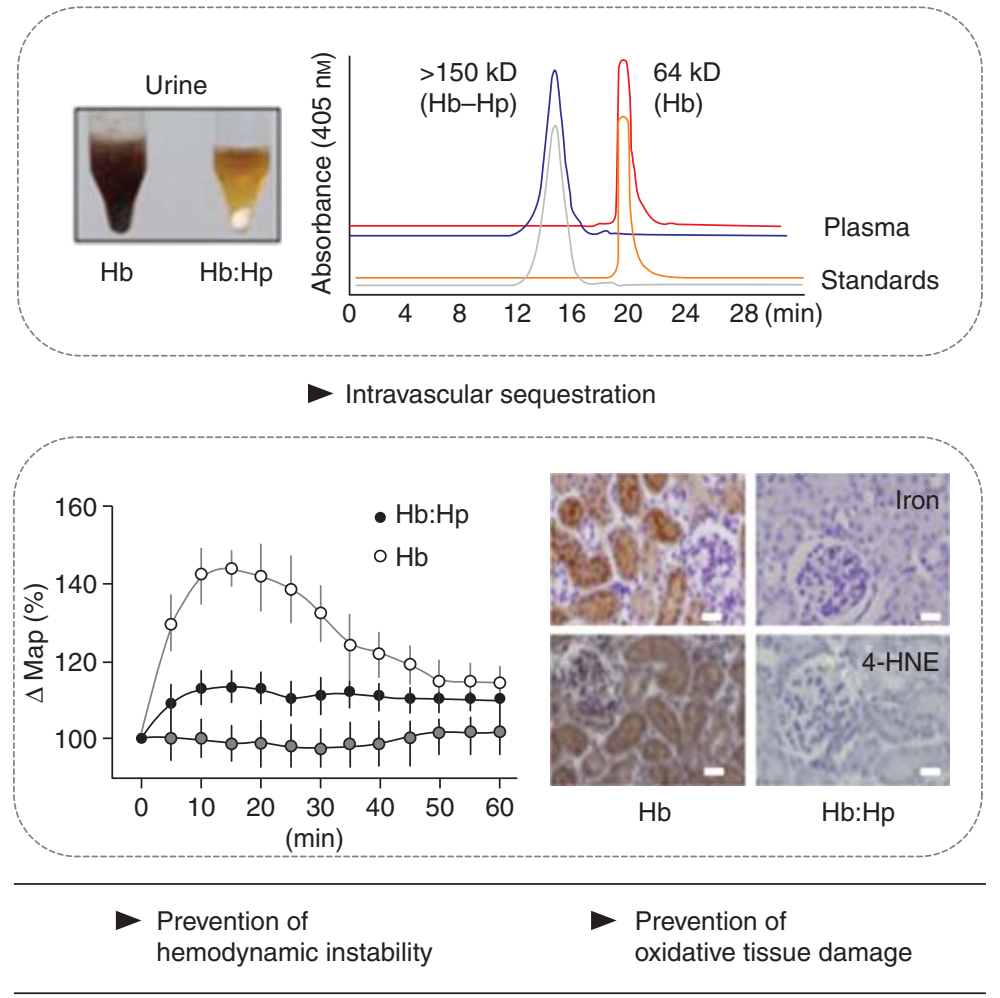

Figure 5. The haptoglobin paradigm of damage prevention during hemolysis. After hemolysis free $\mathrm{Hb}$ can dissociate into $\alpha \beta$ dimers with a relatively small molecule size of $\sim 32 \mathrm{kD}$ (eluting at $19.8 \mathrm{~min}$ in the shown plasma size exclusion chromatography [SEC] profile). Susceptible tissues are exposed to toxic $\mathrm{Hb}$. The results are hemoglobinuria, hemodynamic instability with acute hypertension, and oxidative tissue damage. With haptoglobin ( $\mathrm{Hp}$ ) treatment $100 \%$ of the free $\mathrm{Hb}$ is captured within the large sized ( $>150 \mathrm{kD}) \mathrm{Hb}: \mathrm{Hp}$ complex that elutes at $14.7 \mathrm{~min}$ in plasma SEC (note that there remains no free $\mathrm{Hb}$ in the $\mathrm{Hp}$-treated plasma sample). As a result, free $\mathrm{Hb}$ remains compartmentalized within the circulation. Hemoglobinuria, hemodynamic instability, and oxidative tissue damage are prevented. The image in the left middle panel shows urine collections of $\mathrm{Hb}$ and $\mathrm{Hb}: \mathrm{Hp}$ infused guinea pigs. The lower left panel shows blood pressure recordings of $\mathrm{Hb}, \mathrm{Hb}: \mathrm{Hp}$, or starch (control) infused animals. The kidney sections in the lower right panel were stained for 4-HNE as a marker of oxidative tissue damage (brown color) in $\mathrm{Hb}$-infused (but not in $\mathrm{Hb}$ transfused $+\mathrm{Hp}$-treated) animals. 
studies of the therapeutic potential of $\mathrm{Hp}$ have been conducted in animal models of $\mathrm{Hb}$ infusion and blood transfusion (Boretti et al. 2009; Baek et al. 2012). Application of human plasmaderived $\mathrm{Hp}$ in these models attenuated the $\mathrm{Hb}$-mediated acute hypertensive response, oxidative renal damage, and vascular injury. $\mathrm{Hu}-$ man plasma-derived $\mathrm{Hp}$ is approved as a drug for the treatment of hemolytic conditions in Japan (haptoglobin injection, Benesis, Osaka, Japan). Unfortunately, this product is not available outside of Japan and there are insufficient data available to estimate the clinical efficacy of $\mathrm{Hp}$, but there are reports of therapeutic benefits (Imaizumi et al. 1994). Other Hp products are expected to be developed by European and U.S.-based plasma fractionation companies, and further preclinical and clinical studies will likely be conducted in the near future to further explore the efficacy and safety of $\mathrm{Hp}$ for the treatment of diverse hemolytic conditions.

The rationale for the use of $\mathrm{Hpx}$ as a therapeutic scavenger protein in hemolytic conditions is based on the idea that free heme could be an ultimate mediator of Hb toxicity. This idea is supported by multiple in vitro observations and by findings in the Hpx-knockout mouse, which is susceptible to renal damage after acute intravascular hemolysis (Tolosano et al. 1999). Severe sepsis can be accompanied by hemolysis and Hpx depletion. In a mouse model of severe sepsis, plasma-derived $\mathrm{Hpx}$ was protective against organ damage and death (Larsen et al. 2011). The protective effect in this model may be related to the ability of Hpx to prevent the interaction of free heme with innate immune receptors (e.g., toll-like receptors), interrupting the synergistic proinflammatory effects of heme and the sepsis-inducing pathogen. Currently, there is no Hpx product available for clinical application and, therefore, no safety and/or efficacy data exist for its therapeutic use.

Several functions of Hpx have been described that are not directly related to its heme scavenging activity (Tolosano et al. 2010). These functions involve enzymatic activities as well as direct anti-inflammatory effects. Nonhemebinding effects of Hpx might be responsible for the intriguing observation that, in another mouse model of sepsis, Hpx inhibited neutrophil migration to the focus of infection. In this model, lethality was paradoxically increased in septic wild-type mice treated with the hemebinding protein, and reduced in Hpx-knockout animals (Spiller et al. 2011). It was suggested that many of the reported nonheme-binding functions of Hpx were related to the experimental conditions or to impurities and degradation products in some experimental Hpx preparations (Mauk et al. 2011); careful examination of such effects may be critical in the preclinical evaluation of Hpx-based therapeutics. Also, no comparative experimental data currently exist to determine which of the plasma-scavenging proteins within the $\mathrm{Hb} /$ heme-binding cascade might be the most protective against hemoglobin-driven pathologies.

\section{ACKNOWLEDGMENTS}

This work is supported by the Swiss National Science Foundation (grants 310030/120658 and 31003A/138500), the University of Zurich Research Priority Program "Integrative Human Physiology," the Swiss Federal Commission for Technology and Innovation (CTI), and FDA Internal Funding.

\section{REFERENCES}

Abraham NG, Kappas A. 2008. Pharmacological and clinical aspects of heme oxygenase. Pharmacol Rev 60: 79-127.

Alayash AI. 2004. Oxygen therapeutics: Can we tame haemoglobin? Nat Rev Drug Discov 3: 152-159.

Baek JH, D’Agnillo F, Vallelian F, Pereira CP, Williams MC, Jia Y, Schaer DJ, Buehler PW. 2012. Hemoglobin-driven pathophysiology is an in vivo consequence of the red blood cell storage lesion that can be attenuated in guinea pigs by haptoglobin therapy. J Clin Invest 122: 14441458

Baldwin AL, Wiley EB, Alayash AI. 2002. Comparison of effects of two hemoglobin-based $\mathrm{O}(2)$ carriers on intestinal integrity and microvascular leakage. Am J Physiol Heart Circ Physiol 283: H1292-H1301.

Baldwin AL, Wiley EB, Summers AG, Alayash AI. 2003. Sodium selenite reduces hemoglobin-induced venular leakage in the rat mesentery. Am J Physiol Heart Circ Physiol 284: H81-H91.

Balla J, Jacob HS, Balla G, Nath K, Eaton JW, Vercellotti GM. 1993. Endothelial-cell heme uptake from heme proteins: Induction of sensitization and desensitization to oxidant damage. Proc Natl Acad Sci 90: 9285-9289. 
D.J. Schaer and P.W. Buehler

Baron DM, Yu B, Lei C, Bagchi A, Beloiartsev A, Stowell CP, Steinbicker AU, Malhotra R, Bloch KD, Zapol WM. 2012. Pulmonary hypertension in lambs transfused with stored blood is prevented by breathing nitric oxide. Anesthesiology 116: 637-647.

Barr PJ, Bailie KE. 2011. Transfusion thresholds in FOCUS. N Engl J Med 365: 2532-2533.

Belcher JD, Bryant CJ, Nguyen J, Bowlin PR, Kielbik MC, Bischof JC, Hebbel RP, Vercellotti GM. 2003. Transgenic sickle mice have vascular inflammation. Blood 101: 3953-3959.

Berra L, Coppadoro A, Yu B, Lei C, Spagnolli E, Steinbicker AU, Bloch KD, Lin T, Sammy FY, Warren HS, et al. 2012. Transfusion of stored blood does not alter reactive hyperemia in healthy volunteers. Anesthesiology 117: $56-63$.

Boretti FS, Buehler PW, D’Agnillo F, Kluge K, Glaus T, Butt OI, Jia Y, Goede J, Pereira CP, Maggiorini M, et al. 2009. Sequestration of extracellular hemoglobin within a haptoglobin complex decreases its hypertensive and oxidative effects in dogs and guinea pigs. J Clin Invest 119: 2271-2280.

Boutaud O, Moore KP, Reeder BJ, Harry D, Howie AJ, Wang S, Carney CK, Masterson TS, Amin T, Wright DW, et al. 2010. Acetaminophen inhibits hemoprotein-catalyzed lipid peroxidation and attenuates rhabdomyolysisinduced renal failure. Proc Natl Acad Sci 107: 2699-2704.

Boyle JJ, Harrington HA, Piper E, Elderfield K, Stark J, Landis RC, Haskard DO. 2009. Coronary intraplaque hemorrhage evokes a novel atheroprotective macrophage phenotype. Am J Pathol 174: 1097-1108.

Boyle JJ, Johns M, Kampfer T, Nguyen AT, Game L, Schaer DJ, Mason JC, Haskard DO. 2012. Activating transcription factor 1 directs Mhem atheroprotective macrophages through coordinated iron handling and foam cell protection. Circ Res 110: 20-33.

Buehler PW, D’Agnillo F, Hoffman V, Alayash AI. 2007. Effects of endogenous ascorbate on oxidation, oxygenation, and toxicokinetics of cell-free modified hemoglobin after exchange transfusion in rat and guinea pig. J Pharmacol Exp Ther 323: 49-60.

Buehler PW, Abraham B, Vallelian F, Linnemayr C, Pereira CP, Cipollo JF, Jia Y, Mikolajczyk M, Boretti FS, Schoedon G, et al. 2009. Haptoglobin preserves the CD163 hemoglobin scavenger pathway by shielding hemoglobin from peroxidative modification. Blood 113: 2578-2586.

Buehler PW, D’Agnillo F, Schaer DJ. 2010. Hemoglobinbased oxygen carriers: From mechanisms of toxicity and clearance to rational drug design. Trends $\mathrm{Mol} \mathrm{Med}$ 16: $447-457$.

Bunn HF, Nathan DG, Dover GJ, Hebbel RP, Platt OS, Rosse WF, Ware RE. 2010. Pulmonary hypertension and nitric oxide depletion in sickle cell disease. Blood 116: 687-692.

Butt OI, Buehler PW, D’Agnillo F. 2010. Differential induction of renal heme oxygenase and ferritin in ascorbate and nonascorbate producing species transfused with modified cell-free hemoglobin. Antioxid Redox Signal 12: 199-208.

Cunnington AJ, de Souza JB, Walther M, Riley EM. 2011. Malaria impairs resistance to Salmonella through heme- and heme oxygenase-dependent dysfunctional granulocyte mobilization. Nat Med 18: 120-127.

D'Agnillo F, Alayash AI. 2001. Redox cycling of diaspirin cross-linked hemoglobin induces G2/M arrest and apoptosis in cultured endothelial cells. Blood 98: 3315-3323.

Doherty DH, Doyle MP, Curry SR, Vali RJ, Fattor TJ, Olson JS, Lemon DD. 1998. Rate of reaction with nitric oxide determines the hypertensive effect of cell-free hemoglobin. Nat Biotechnol 16: 672-676.

Donadee C, Raat NJ, Kanias T, Tejero J, Lee JS, Kelley EE, Zhao X, Liu C, Reynolds H, Azarov I, et al. 2011. Nitric oxide scavenging by red blood cell microparticles and cell-free hemoglobin as a mechanism for the red cell storage lesion. Circulation 124: 465-476.

Etzerodt A, Maniecki MB, Moller K, Moller HJ, Moestrup SK. 2010. Tumor necrosis factor $\alpha$-converting enzyme (TACE/ADAM17) mediates ectodomain shedding of the scavenger receptor CD163. J Leukoc Biol 88: 1201-1205.

Farber HW, Loscalzo J. 2004. Pulmonary arterial hypertension. N Engl J Med 351: 1655-1665.

Ferreira A, Marguti I, Bechmann I, Jeney V, Chora A, Palha NR, Rebelo S, Henri A, Beuzard Y, Soares MP. 2011. Sickle hemoglobin confers tolerance to Plasmodium infection. Cell 145: 398-409.

Finn AV, Nakano M, Polavarapu R, Karmali V, Saeed O, Zhao X, Yazdani S, Otsuka F, Davis T, Habib A, et al. 2012. Hemoglobin directs macrophage differentiation and prevents foam cell formation in human atherosclerotic plaques. J Am Coll Cardiol 59: 166-177.

Gladwin MT, Sachdev V, Jison ML, Shizukuda Y, Plehn JF, Minter K, Brown B, Coles WA, Nichols JS, Ernst I, et al. 2004. Pulmonary hypertension as a risk factor for death in patients with sickle cell disease. $N$ Engl J Med 350: 886-895.

Gladwin MT, Kanias T, Kim-Shapiro DB. 2012. Hemolysis and cell-free hemoglobin drive an intrinsic mechanism for human disease. J Clin Invest 122: 1205-1208.

Gramaglia I, Sobolewski P, Meays D, Contreras R, Nolan JP, Frangos JA, Intaglietta M, van der Heyde HC. 2006. Low nitric oxide bioavailability contributes to the genesis of experimental cerebral malaria. Nat Med 12: 1417-1422.

Heller A, Ragaller M, Schmeck J, Fluth H, Muller M, Albrecht DM, Koch T. 1998. Role of NO and endothelin in hemoglobin-induced pulmonary vasoconstriction. Shock 10: 401-406.

Hod EA, Zhang N, Sokol SA, Wojczyk BS, Francis RO, Ansaldi D, Francis KP, Della-Latta P, Whittier S, Sheth S, et al. 2010. Transfusion of red blood cells after prolonged storage produces harmful effects that are mediated by iron and inflammation. Blood 115: 4284-4292.

Hod EA, Brittenham GM, Billote GB, Francis RO, Ginzburg YZ, Hendrickson JE, Jhang J, Schwartz J, Sharma S, Sheth S, et al. 2011. Transfusion of human volunteers with older, stored red blood cells produces extravascular hemolysis and circulating non-transferrin-bound iron. Blood 118: 6675-6682.

Imaizumi $\mathrm{H}$, Tsunoda $\mathrm{K}$, Ichimiya N, Okamoto T, Namiki A. 1994. Repeated large-dose haptoglobin therapy in an extensively burned patient: Case report. J Emerg Med 12: $33-37$. 
Jeney V, Balla J, Yachie A, Varga Z, Vercellotti GM, Eaton JW Balla G. 2002. Pro-oxidant and cytotoxic effects of circulating heme. Blood 100: 879-887.

Jia Y, Buehler PW, Boykins RA, Venable RM, Alayash AI. 2007. Structural basis of peroxide-mediated changes in human hemoglobin: A novel oxidative pathway. J Biol Chem 282: 4894-4907.

Kaempfer T, Duerst E, Gehrig P, Roschitzki B, Rutishauser D, Grossmann J, Schoedon G, Vallelian F, Schaer DJ. 2011. Extracellular hemoglobin polarizes the macrophage proteome toward $\mathrm{Hb}$-clearance, enhanced antioxidant capacity and suppressed HLA class 2 expression. Proteome Res 10: 2397-2408.

Kolodgie FD, Gold HK, Burke AP, Fowler DR, Kruth HS, Weber DK, Farb A, Guerrero LJ, Hayase M, Kutys R, et al. 2003. Intraplaque hemorrhage and progression of coronary atheroma. N Engl J Med 349: 2316-2325.

Kristiansen M, Graversen JH, Jacobsen C, Sonne O, Hoffman HJ, Law SK, Moestrup SK. 2001. Identification of the haemoglobin scavenger receptor. Nature 409: $198-$ 201.

Larsen R, Gozzelino R, Jeney V, Tokaji L, Bozza FA, Japiassu AM, Bonaparte D, Cavalcante MM, Chora A, Ferreira A, et al. 2011. A central role for free heme in the pathogenesis of severe sepsis. Sci Transl Med 2: 51ra71.

Levy AP, Asleh R, Blum S, Levy NS, Miller-Lotan R, KaletLitman S, Anbinder Y, Lache O, Nakhoul FM, Asaf R, et al. 2010. Haptoglobin: Basic and clinical aspects. Antioxid Redox Signal 12: 293-304

Lin T, Kwak YH, Sammy F, He P, Thundivalappil S, Sun G Chao W, Warren HS. 2010. Synergistic inflammation is induced by blood degradation products with microbial Toll-like receptor agonists and is blocked by hemopexin. J Infect Dis 202: 624-632.

Lin S, Zhong Q, Lv FL, Zhou Y, Li JQ, Wang JZ, Yang QW, Yin Q. 2012. Heme activates TLR4-mediated inflammatory injury via MyD88/TRIF signaling pathway in intracerebral hemorrhage. J Neuroinflammation 9: 46.

Mauk MR, Smith A, Mauk AG. 2011. An alternative view of the proposed alternative activities of hemopexin. Protein Sci 20: 791-805.

Middelburg RA, van den Watering LM, Briet E, van der Bom JG. 2012. Storage time of red blood cells and mortality of transfusion recipients. Transfus Med Rev 27: $36-43$.

Miller YI, Altamentova SM, Shaklai N. 1997. Oxidation of low-density lipoprotein by hemoglobin stems from a heme-initiated globin radical: Antioxidant role of haptoglobin. Biochemistry 36: 12189-12198.

Minneci PC, Deans KJ, Zhi H, Yuen PS, Star RA, Banks SM, Schechter AN, Natanson C, Gladwin MT, Solomon SB. 2005. Hemolysis-associated endothelial dysfunction mediated by accelerated NO inactivation by decompartmentalized oxyhemoglobin. J Clin Invest 115: 3409-3417.

Moore KP, Holt SG, Patel RP, Svistunenko DA, Zackert W, Goodier D, Reeder BJ, Clozel M, Anand R, Cooper CE, et al. 1998. A causative role for redox cycling of myoglobin and its inhibition by alkalinization in the pathogenesis and treatment of rhabdomyolysis-induced renal failure. $J$ Biol Chem 273: 31731-31737.

Nagy E, Eaton JW, Jeney V, Soares MP, Varga Z, Galajda Z, Szentmiklosi J, Mehes G, Csonka T, Smith A, et al. 2010
Red cells, hemoglobin, heme, iron, and atherogenesis. Arterioscler Thromb Vasc Biol 30: 1347-1353.

Natanson C, Kern SJ, Lurie P, Banks SM, Wolfe SM. 2008. Cell-free hemoglobin-based blood substitutes and risk of myocardial infarction and death: A meta-analysis. JAMA 299: 2304-2312.

Nielsen MJ, Moller HJ, Moestrup SK. 2010. Hemoglobin and heme scavenger receptors. Antioxid Redox Signal 12: 261-273.

Olson JS, Foley EW, Rogge C, Tsai AL, Doyle MP, Lemon DD. 2004. NO scavenging and the hypertensive effect of hemoglobin-based blood substitutes. Free Radic Biol Med 36: 685-697.

Otterbein LE, Soares MP, Yamashita K, Bach FH. 2003. Heme oxygenase-1: Unleashing the protective properties of heme. Trends Immunol 24: 449-455.

Pamplona A, Ferreira A, Balla J, Jeney V, Balla G, Epiphanio S, Chora A, Rodrigues CD, Gregoire IP, CunhaRodrigues M, et al. 2007. Heme oxygenase-1 and carbon monoxide suppress the pathogenesis of experimental cerebral malaria. Nat Med 13: 703-710.

Parent F, Bachir D, Inamo J, Lionnet F, Driss F, Loko G, Habibi A, Bennani S, Savale L, Adnot S, et al. 2011. A hemodynamic study of pulmonary hypertension in sickle cell disease. N Engl J Med 365: 44-53.

Pimenova T, Pereira CP, Gehrig P, Buehler PW, Schaer DJ, Zenobi R. 2010. Quantitative mass spectrometry defines an oxidative hotspot in hemoglobin that is specifically protected by haptoglobin. J Proteome Res 9: 4061-4070.

Reiter CD, Wang X, Tanus-Santos JE, Hogg N, Cannon RO III, Schechter AN, Gladwin MT. 2002. Cell-free hemoglobin limits nitric oxide bioavailability in sickle-cell disease. Nat Med 8: 1383-1389.

Roche C, Dantsker D, Alayash AI, Friedman JM. 2012. Enhanced nitrite reductase activity associated with the haptoglobin complexed hemoglobin dimer: Functional and antioxidative implications. Nitric Oxide 27: 32-39.

Rosenthal PJ. 2011. Lessons from sickle cell disease in the treatment and control of malaria. $N$ Engl J Med 364: 2549-2551.

Rother RP, Bell L, Hillmen P, Gladwin MT. 2005. The clinical sequelae of intravascular hemolysis and extracellular plasma hemoglobin: A novel mechanism of human disease. JAMA 293: 1653-1662.

Schaer DJ, Alayash AI. 2012. Clearance and control mechanisms of hemoglobin from cradle to grave. Antioxid Redox Signal 12: 181-184.

Schaer DJ, Schleiffenbaum B, Kurrer M, Imhof A, Bachli E, Fehr J, Moller HJ, Moestrup SK, Schaffner A. 2005. Soluble hemoglobin-haptoglobin scavenger receptor CD163 as a lineage-specific marker in the reactive hemophagocytic syndrome. Eur J Haematol 74: 6-10.

Schaer CA, Schoedon G, Imhof A, Kurrer MO, Schaer DJ. 2006a. Constitutive endocytosis of CD163 mediates hemoglobin-heme uptake and determines the noninflammatory and protective transcriptional response of macrophages to hemoglobin. Circ Res 99: 943-950.

Schaer DJ, Schaer CA, Buehler PW, Boykins RA, Schoedon G, Alayash AI, Schaffner A. 2006b. CD163 is the macrophage scavenger receptor for native and chemically 
D.J. Schaer and P.W. Buehler

modified hemoglobins in the absence of haptoglobin. Blood 107: 373-380.

Schaer CA, Vallelian F, Imhof A, Schoedon G, Schaer DJ. 2007. CD163-expressing monocytes constitute an endotoxin-sensitive $\mathrm{Hb}$ clearance compartment within the vascular system. J Leukoc Biol 82: 106-110.

Silverman TA, Weiskopf RB. 2009. Hemoglobin-based oxygen carriers: Current status and future directions. Anesthesiology 111: 946-963.

Spiller F, Costa C, Souto FO, Vinchi F, Mestriner FL, Laure HJ, Alves-Filho JC, Freitas A, Rosa JC, Ferreira SH, et al. 2011. Inhibition of neutrophil migration by hemopexin leads to increased mortality due to sepsis in mice. Am J Respir Crit Care Med 183: 922-931.

Tolosano E, Hirsch E, Patrucco E, Camaschella C, Navone R, Silengo L, Altruda F. 1999. Defective recovery and severe renal damage after acute hemolysis in hemopexin-deficient mice. Blood 94: 3906-3914.

Tolosano E, Fagoonee S, Morello N, Vinchi F, Fiorito V. 2010. Heme scavenging and the other facets of hemopexin. Antioxid Redox Signal 12: 305-320.

Vallelian F, Pimenova T, Pereira CP, Abraham B, Mikolajczyk MG, Schoedon G, Zenobi R, Alayash AI Buehler PW, Schaer DJ. 2008. The reaction of hydrogen peroxide with hemoglobin induces extensive $\alpha$-globin crosslinking and impairs the interaction of hemoglobin with endogenous scavenger pathways. Free Radic Biol Med 45: 1150-1158.

Vallelian F, Schaer CA, Kaempfer T, Gehrig P, Duerst E, Schoedon G, Schaer DJ. 2010. Glucocorticoid treatment skews human monocyte differentiation into a hemoglo- bin-clearance phenotype with enhanced heme-iron recycling and antioxidant capacity. Blood 116: 5347-5356.

Wang D, Sun J, Solomon SB, Klein HG, Natanson C. 2012. Transfusion of older stored blood and risk of death: A meta-analysis. Transfusion 52: 1184-1195.

Wicher KB, Fries E. 2010. Evolutionary aspects of hemoglobin scavengers. Antioxid Redox Signal 12: 249-259.

Yachie A, Niida Y, Wada T, Igarashi N, Kaneda H, Toma T, Ohta K, Kasahara Y, Koizumi S. 1999. Oxidative stress causes enhanced endothelial cell injury in human heme oxygenase-1 deficiency. J Clin Invest 103: 129-135.

Yazdanbakhsh K, Bao W, Zhong H. 2011. Immunoregulatory effects of stored red blood cells. Hematology Am Soc Hematol Educ Program 2011: 466-469.

Yu B, Raher MJ, Volpato GP, Bloch KD, Ichinose F, Zapol WM. 2008. Inhaled nitric oxide enables artificial blood transfusion without hypertension. Circulation 117: 1982-1990.

Yu B, Volpato GP, Chang K, Bloch KD, Zapol WM. 2009. Prevention of the pulmonary vasoconstrictor effects of HBOC-201 in awake lambs by continuously breathing nitric oxide. Anesthesiology 110: 113-122.

Yu B, Lei C, Baron DM, Steinbicker AU, Bloch KD, Zapol WM. 2012. Diabetes augments and inhaled nitric oxide prevents the adverse hemodynamic effects of transfusing syngeneic stored blood in mice. Transfusion 52: 14101422 .

Zager RA, Gamelin LM. 1989. Pathogenetic mechanisms in experimental hemoglobinuric acute renal failure. Am J Physiol 256: F446-F455. 


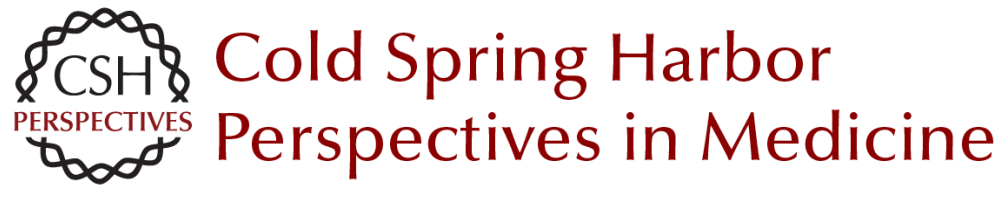

\section{Cell-Free Hemoglobin and Its Scavenger Proteins: New Disease Models Leading the Way to Targeted Therapies}

Dominik J. Schaer and Paul W. Buehler

Cold Spring Harb Perspect Med 2013; doi: 10.1101/cshperspect.a013433 originally published online May 3, 2013

Subject Collection Hemoglobin and Its Diseases

The Natural History of Sickle Cell Disease

Graham R. Serjeant

Current Management of Sickle Cell Anemia Patrick T. McGann, Alecia C. Nero and Russell E. Ware

Cell-Free Hemoglobin and Its Scavenger Proteins:

New Disease Models Leading the Way to Targeted

Therapies

Dominik J. Schaer and Paul W. Buehler

Clinical Manifestations of $\alpha$-Thalassemia Elliott P. Vichinsky

Erythroid Heme Biosynthesis and Its Disorders Harry A. Dailey and Peter N. Meissner

Hemoglobin Variants: Biochemical Properties and

Clinical Correlates Christopher S. Thom, Claire F. Dickson, David A. Gell, et al.

The Prevention of Thalassemia Antonio Cao and Yuet Wai Kan

The Switch from Fetal to Adult Hemoglobin Vijay G. Sankaran and Stuart H. Orkin
Transcriptional Mechanisms Underlying

Hemoglobin Synthesis

Koichi R. Katsumura, Andrew W. DeVilbiss,

Nathaniel J. Pope, et al.

Iron Deficiency Anemia: A Common and Curable

Disease Jeffery L. Miller

Management of the Thalassemias

Nancy F. Olivieri and Gary M. Brittenham

The Molecular Basis of $\beta$-Thalassemia Swee Lay Thein

Erythropoiesis: Development and Differentiation Elaine Dzierzak and Sjaak Philipsen

Erythropoietin H. Franklin Bunn

Classification of the Disorders of Hemoglobin Bernard G. Forget and H. Franklin Bunn

The Molecular Basis of $\alpha$-Thalassemia Douglas R. Higgs

For additional articles in this collection, see http://perspectivesinmedicine.cshlp.org/cgi/collection/ 